between ecologically distinct regions ${ }^{9}$. Will Andean wealth inequalities rank closer to those of Old World societies, or to their North American neighbours?

Furthermore, it is important to acknowledge that the 'Old World' was a vast space, characterized by tremendously diverse biogeography, cultures and economies. In Kohler and colleagues' study it is represented by only 25 sites spanning some 9,000 years, which leaves large gaps in time and space. A more-robust sample of sites that includes greater swathes of Europe, Asia and Africa is needed to determine more precisely how the presence of large domesticated animals was related to growing inequality. Other differences between the Old and New worlds, such as more-sophisticated metallurgy in the Old World, and the possibility that some large New World political systems had more-collective forms of governance ${ }^{10,11}$, may also be fruitful lines of enquiry. -

Michelle Elliott is in the UMR 7041 and the UFR03 Histoire de l'Art et Archéologie, Université Paris 1, Panthéon-Sorbonne, Paris 75006, France.

e-mail:michelle.elliott@univ-paris1.fr

1. United Nations. The Sustainable Development Goals Report 2017 (UN, 2017)

2. Piketty, T. Le Capital au XXIe Siècle (Le Seuil, 2013).

3. Kohler, T. A. et al. Nature 551, 619-622 (2017).

4. Flannery, K. \& Marcus, J. The Creation of Inequality
(Harvard Univ. Press, 2012).

5. Earle, T. \& Kristiansen, K. Organizing Bronze Age Societies (Cambridge Univ. Press, 2010).

6. Pearson, R., Lee, J., Koh, W. \& Underhill, A J. Anthropol. Archaeol. 8, 1-50 (1989).

7. Gini, C. Variabilità e Mutabilità (1912); reprinted in Memorie di Metodologica Statistica (eds Pizetti, E. \& Salvemini, T.) (Libreria Eredi Virgilio Veschi, 1955).

8. Diamond, J. Guns, Germs, and Steel: The Fates of Human Societies (Norton, 1999).

9. Bonavia, D. The South American Camelids: An Expanded and Corrected Edition (UCLA-Cotsen Inst. Archaeol. Press, 2009)

10.Carballo, D. M. Cooperation and Collective Action: Archaeological Perspectives (Univ. Press Colorado, 2013).

11.Blanton, R. E., Feinman, G. M., Kowalewski, S. A. \& Peregrine, P. N. Curr. Anthropol. 37, 1-14 (1996).

This article was published online on 15 November 2017.

\section{Methane upgraded by rhodium}

\section{Rhodium catalysts have been developed that can be tuned to produce two different products from methane. The findings could aid the development of industrial processes that exploit this abundant resource. SEE LETTER P.605}

\section{IVE HERMANS}

$\mathrm{M}$ ethane is an underused resource, in part because technologies for converting it into more-valuable chemicals are highly underdeveloped, presenting a major challenge for chemists ${ }^{1,2}$. On page 605 , Shan et al. ${ }^{3}$ address this challenge by reporting rhodium catalysts that promote the oxidation of methane to either methanol $\left(\mathrm{CH}_{3} \mathrm{OH}\right)$ or acetic acid $\left(\mathrm{CH}_{3} \mathrm{COOH}\right)$. The optimized catalytic systems provide mechanistic insight into these reactions, which might inform the development of industrial processes for preparing useful products from methane.

The availability of natural-gas resources from fracking (hydraulic fracturing) has transformed the US chemical industry. Most of the investment and growth ${ }^{4-6}$ has been in the production of ethylene $\left(\mathrm{CH}_{2}=\mathrm{CH}_{2}\right)$, which is widely used as a chemical building block in the industrial synthesis of other compounds, particularly polythene (polyethylene). Ethylene was conventionally produced by processes broadly known as cracking, in which the components of naphtha fractions derived from crude oil are broken down into smaller molecules. However, many cracker facilities have now been retrofitted to use cheap natural gas as a feedstock, greatly reducing production costs. This has encouraged petrochemical companies to invest in new projects in the United States, or to expand their capacities $^{5}$, thus generating new jobs.

A side effect of this feedstock shift is that higher olefins - compounds such as propylene $\left(\mathrm{CH}_{3} \mathrm{CH}=\mathrm{CH}_{2}\right)$ and isomers of butylene $\left(\mathrm{C}_{4} \mathrm{H}_{8}\right)$, which were also formed by cracking - are now produced globally in lower quantities than before ${ }^{1,2,4}$. Moreover, there is an abundance of methane $\left(\mathrm{CH}_{4}\right.$, the main component of natural gas), which was already an underused resource before fracking started. The development of 'on-purpose' methods for making olefins from the corresponding small alkanes, such as propane $\left(\mathrm{CH}_{3} \mathrm{CH}_{2} \mathrm{CH}_{3}\right)$ and isomers of butane $\left(\mathrm{C}_{4} \mathrm{H}_{10}\right)$, found in natural gas, has therefore become a hot research topic, and the number of emerging technologies in this field has grown ${ }^{7-10}$. But the methods available for 'upgrading' methane by converting it into more-valuable chemicals have been limited.

One currently available methane-upgrading process converts the gas into carbon monoxide and hydrogen, a mixture known as synthesis gas (Fig. 1). This mixture can then be converted into methanol or hydrocarbons using the Fischer-Tropsch process ${ }^{11}$. But methane upgrading via synthesis gas is generally energy-intensive and can be expensive (although the costs are currently offset by the low cost of methane). The direct conversion of methane into value-added chemicals in economically viable processes therefore remains an outstanding goal of the chemical industry, and one that many researchers have pursued for decades. The required capital investments, and the fact that the synthesisgas approach is currently relatively cheap, means that direct methane-upgrading technology will have to be substantially more economical than other established processes if it is to be adopted.

Shan and colleagues' catalytic systems not only enable direct upgrading of methane, but also offer a choice of products. The catalysts consist of rhodium (Rh) dispersed on either a zeolite (ZSM-5, a crystalline, porous solid) or titanium dioxide $\left(\mathrm{TiO}_{2}\right)$. In the presence of carbon monoxide and oxygen, the catalysts

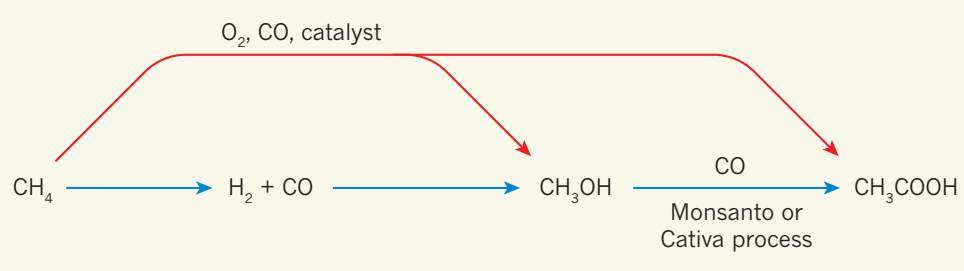

Figure 1 | Chemical routes for making value-added products from methane. A conventional approach for converting methane $\left(\mathrm{CH}_{4}\right)$ into more-valuable products is shown in blue arrows. Methane is first converted into synthesis gas (a mixture of hydrogen and carbon monoxide), which is then turned into methanol $\left(\mathrm{CH}_{3} \mathrm{OH}\right)$. The methanol can then be reacted with carbon monoxide to generate acetic acid $\left(\mathrm{CH}_{3} \mathrm{COOH}\right)$, using either the Monsanto process or the Cativa process. Shan et al. ${ }^{3}$ report rhodium catalysts that can be tuned to convert methane directly into methanol or acetic acid, in the presence of oxygen and carbon monoxide (red arrows). 
convert methane to either acetic acid or methanol, depending on the acidity of the supporting material (Fig. 1). Acetic acid is currently largely produced by the reaction of methanol with carbon monoxide in the rhodium-catalysed Monsanto process or the iridium-catalysed Cativa process ${ }^{12}$.

The authors' optimized Rh-ZSM- 5 catalyst produces about 0.4 kilograms of acetic acid per kilogram of catalyst per hour, using methane, carbon monoxide and oxygen at a total pressure of less than $30 \mathrm{bar}$, and water as a solvent. Although this formation rate is probably too low to make the reaction economically viable, it is a remarkable step forward. By exchanging the hydrogen ions in the porous zeolite for sodium ions, the authors could eliminate the acidity of the catalyst, thus tuning it to make methanol rather than acetic acid. Similarly, the $\mathrm{Rh} / \mathrm{TiO}_{2}$ catalyst produces methanol because titanium dioxide isn't acidic. These results open the door to a more-extensive investigation of the effects of the supports in the future. Interestingly, the methanol-forming reaction requires carbon monoxide to be present, even though this gas is not a reactant.

Using a variety of spectroscopic and microscopic characterization techniques, Shan et al. conclude that individual rhodium species isolated inside pores in the supports are responsible for catalysis. The authors also found that the way in which the catalyst is prepared is crucial for controlling the distribution and form of rhodium species: heating the catalyst in air favours the undesirable formation of nanoparticles of rhodium oxide, whereas heat treatment under hydrogen gas maximizes the amount of isolated rhodium species predominantly in the +1 oxidation state.

Shan and colleagues propose an organometallic mechanism for the reaction, on the basis of the observed correlation between catalytic activity and the presence of isolated rhodium(I) species. In the first step, a stable intermediate containing a $\mathrm{Rh}-\mathrm{CH}_{3}$ group forms when the metal comes into contact with methane and oxygen. This intermediate then reacts with carbon monoxide to form acetic acid presumably, because the carbon monoxide inserts itself into the $\mathrm{Rh}-\mathrm{CH}_{3}$ bond to form an acetyl intermediate $\left(\mathrm{Rh}-\mathrm{COCH}_{3}\right)$, which is then hydrolysed to yield acetic acid.

On the basis of the observation that methanol, rather than acetic acid, forms when hydrogen ions are eliminated from the catalyst support, the authors hypothesize that the ions facilitate the insertion of carbon monoxide into $\mathrm{Rh}-\mathrm{CH}_{3}$. In the absence of those ions, an oxygen atom instead inserts into the $\mathrm{Rh}-\mathrm{CH}_{3}$ intermediate to form a $\mathrm{Rh}-\mathrm{OCH}_{3}$ group, but only in the presence of carbon monoxide molecules; hydrolysis of the $\mathrm{Rh}-\mathrm{OCH}_{3}$ group then generates methanol. Carbon monoxide therefore acts as a co-catalyst in the conversion of methane to methanol.

The proposed mechanism lays the groundwork for further studies of the versatility of the catalytic system. For instance, understanding how solvents affect the reaction might provide a viable method for making other value-added products from methane. Such versatility would be a good starting point for the development of inexpensive, efficient technologies for upgrading methane from natural-gas sources.

Perhaps the most exciting aspect of this work is the discovery that the catalytically active sites are dispersed rhodium complexes, rather than rhodium nanoparticles, as many chemists might have expected. Shan and colleagues' work therefore links homogeneous organometallic chemistry - which typically involves the reactivity of individual metal complexes - with solid-phase (heterogeneous) catalysis, and illustrates the importance of understanding catalysts at the atomic scale. The findings therefore open up interesting opportunities for exploring the field of heterogeneous catalysis. -

Ive Hermans is in the Department of Chemistry, and the Department of Chemical and Biological Engineering, University of Wisconsin-Madison, Madison, Wisconsin 53706, USA.

e-mail:hermans@chem.wisc.edu

1. Gunsalus, N. J. et al. Chem. Rev. 117, 8521-8573 (2017).

2. Schwach, P., Pan, X. \& Bao, X. Chem. Rev. 117, 8497-8520 (2017).

3. Shan, J., Li, M., Allard, L. F., Lee, F. \& Flytzani-Stephanopoulos, F. Nature 551, 605-608 (2017).

4. Sattler, J. J. H. B., Ruiz-Martinez, J., Santillan-Jimenez, E. \& Weckhuysen, B. M. Chem. Rev. 114, 10613-10653 (2014).

5. Armor, J. N. J. Energy Chem. 22, 21-26 (2013).

6. Rightor, E. G. \& Tway, C. L. Catal. Today 258 , 226-229 (2015).

7. Venegas, J. M. et al. ChemCatChem 9, 2118-2127 (2017).

8. Carrero, C. A., Schloegl, R., Wachs, I. E. \& Schomaecker, R. ACS Catal. 4, 3357-3380 (2014).

9. Bricker, J. C. Top. Catal. 55, 1309-1314 (2012).

10.Ren, T., Patel, M. \& Blok, K. Energy 31, 425-451 (2006).

11.de Klerk, A. in Kirk-Othmer Encyclopedia of Chemical Technology (ed. Seidel, A.) 1-20 (Wiley, 2013).

12.Wagner, F. S. in Kirk-Othmer Encyclopedia of Chemical Technology (ed. Seidel, A.) 14.a01.pub3 (Wiley, 2014)

\section{Bulky tether proteins aid membrane fusion}

\section{The energy source that drives vesicle fusion with a target organelle in vivo has been unclear. It emerges that proteins that tether fusing structures together also decrease the energy needed for the final fusion step. SEE LETTER P.634}

\section{ANNE SPANG}

$\longrightarrow$ ells communicate with each other by releasing and taking up molecular 'messages', which are often proteins or hormones. These signalling components are delivered to the cell membrane through a pathway in which vesicles containing these molecules transit through different organelles by a series of vesicle budding and fusion events. However, many questions remain about the mechanisms driving the regulation and execution of the membrane fusion (in which the lipid bilayers on two separate membranes fuse to form one bilayer) underlying this process. D'Agostino et al. ${ }^{1}$ reveal on page 634 that proteins that act at an early stage of membrane fusion also have a role in the key final event of the fusion process.

SNAREs are a group of membrane proteins present on the surface of vesicles and organelles. They help to ensure that vesicles fuse with the correct target compartment through a lock-and-key-like process in which $\alpha$-helical structural regions of SNAREs on different membranes intertwine and zipper together to form a structure called a trans-SNARE complex $^{2}$. However, SNARE proteins have only a small cytoplasmic domain that is probably too short to bring a vesicle close to the organelle that is its fusion target (although SNARE proteins are sufficient to drive membrane fusion in reconstituted cell-free in vitro systems ${ }^{3}$ ). Instead, the process called docking establishes the first physical contact between a vesicle and the target membrane. This step requires a group of proteins called tethers, which can be extended coiled-coil proteins or multi-subunit tether complexes. Tethers determine whether a potential fusion interaction should occur, through recognition of specific proteins found on a vesicle surface, such as Rab proteins or coat proteins ${ }^{4}$.

After the initial recognition step, tethers bring the vesicle into closer contact with the target membrane until interaction between SNAREs leads to trans-SNARE-complex formation and membrane fusion ${ }^{2}$. This 